\title{
Contribution of tick-borne diseases to mortality in juvenile free-living cervids
}

\author{
Dorota Dwużnik-Szarek ${ }^{1, B-C, E-F \oplus}$, Maciej Kowalec ${ }^{1, C, E-F \oplus}$, Mustafa Alsarraf ${ }^{1, B-C, F \oplus}$, Anna Bajer ${ }^{1, A-F \circledast ~}$ \\ 'Department of Eco-Epidemiology of Parasitic Diseases, Institute of Developmental Biology and Biomedical Sciences, \\ Faculty of Biology, University of Warsaw, Poland \\ A - Research concept and design, B - Collection and/or assembly of data, C - Data analysis and interpretation, \\ $D$ - Writing the article, $E$ - Critical revision of the article, $F$ - Final approval of the article
}

Dwużnik-Szarek D, Kowalec M, Alsarraf M, Bajer A. Contribution of tick-borne diseases to mortality in juvenile free-living cervids. Ann Agric Environ Med. 2022; 29(2): 215-219. doi: 10.26444/aaem/142513

\begin{abstract}
Introduction and objective. Reports on tick-borne infections in free-living juvenile animals and their impact on survival of cervids in nature are lacking. The aim of the study was to detect and identify the Babesia and Anaplasma phagocytophilum species/ecotypes that may have contributed to the death of juvenile animals from a wildlife rescue centre in spring 2020.

Materials and method. PCR amplification and sequencing of two genetic markers (18S rDNA and cox 1 for Babesia, 16S rDNA and groEL for A. phagocytophilum) were used for screening eleven samples derived from juvenile animals which died in a rescue centre (seven roe deer Capreolus capreolus, one elk Alces alces, one red squirrel Sciurus vulgaris, one European beaver Castor fiber, one red fox Vulpes vulpes). Phylogenetic analysis of full-length 18S rDNA sequence was performed to enable differentiation between two closely-related species infecting wild ungulates, Babesia capreoli and Babesia divergens (zoonotic).

Results. The occurrence of the typical SNPs of B. capreoli at two discriminating positions in the 18S rRNA gene allowed identification of $B$. capreoli infection in a roe deer calf. In two calves, Anaplasma phagocytophilum ecotype 2 was identified, including the same calf co-infection. No Babesia DNA was amplified in an elk calf treated for babesiosis. Splenomegaly was recorded in roe deer calves with A. phagocytophilum and A. phagocytophilum + B. capreoli infection.

Conclusions. The study revealed that tick-borne infections are common among juvenile, free-living cervids and may contribute to their mortality.
\end{abstract}

Key words

Anaplasma phagocytophilum, roe deer, Babesia capreoli, Eurasian elk, fatal babesiosis

\section{INTRODUCTION}

Ungulates, especially cervids (Cervidae), are key players in some host-vector-pathogen interactions, acting as reservoir hosts for many pathogens and as the main source of blood meals for Ixodes ricinus females [1, 2].

In Poland, roe deer (Capreolus capreolus) is the most abundant member of the Cervidae family [3, 4, 5]. Both roe deer and Eurasian elk (Alces alces alces Linnaeus, 1758) are classified as a game species; however, since 2001, elk have been protected by law throughout the whole year (Dz. U. 2001, No. 43, position 488). This species was almost exterminated after World War II after which it was actively protected and its survival aided by being reintroduced in some parts of the country, i.e., in Central Poland, in the Kampinoski National Park near Warsaw in 1951 (https://www.kampinoski-pn.gov. pl/przyroda/fauna). Since 2001, elk populations have grown and spread considerably in Poland, reaching a population size of some 23,700 individuals by 2019 [5]. Eurasian elk is still considered a rare and protected species, and our knowledge of the natural diseases that limit their survival in nature is still insufficient $[6,7]$.

Generally, the impact of vector-borne diseases, including tick-borne babesiosis, on populations of free-living mammals is still poorly understood due to the difficulties inherent in

Address for correspondence: Dorota Dwużnik-Szarek, University of Warsaw, Miecznikowa 1, 02-096 Warsaw, Poland

E-mail: dorota.dwuznik@biol.uw.edu.pl

Received: 18.08.2021; accepted: 22.09.2021; first published: 21.10.2021 monitoring naturally infected wild individuals. In some populations, i.e. in the red fox, tick-borne infections are very abundant and their impact on survival appears to be generally modest $[8,9]$. However, to our knowledge, the contribution of tick-borne diseases to mortality among juvenile wildlife in general, and cervid calves particular, has not been intensively investigated. The current study was performed following information on the death of an elk calf which died in a rescue centre, having presented with clinical signs of acute babesiosis. Molecular techniques were used to detect the presence of tick-borne pathogens among juvenile mammals which died despite treatment in this centre in spring 2020.

\section{MATERIALS AND METHOD}

Ethical issue. No animals were culled for this study. Since the study was carried out on blood and tissue samples provided by the veterinary staff of a wildlife rescue centre, no ethical approval/ license was required (as per the Resolution on the Protection of Animals used for Scientific or Educational Purposes, 15 January 2015: Dz. U. 2015 position 266, Chapter 1, Paragraph 1.2.1).

In July 2020, eleven blood and spleen samples were obtained from a wildlife rescue centre in Central Poland. The samples were derived from seven juvenile roe deer and one elk calf (Tab. 1). The deer calves died likely due to serious injuries and trauma $(n=7)$, mostly attributable to traffic collisions, 
and from unknown reasons $(n=2)$. The elk calf died of suspected babesiosis. Additionally, one juvenile European beaver (Castor fiber), one red squirrel (Sciurus vulgaris) and one red fox pup were screened.

Elk - case description. A female elk calf about two weeks old was found abandoned, weakened and tick-infested. The calf was observed over a three-day period, with no signs of its mother it had sought the company of horses. At clinical presentation on the 7 June 2020, the calf was emaciated and dehydrated. It was immediately administered intravenous fluids ( $0.9 \%$ saline, electrolytes [Optylite]), and was fed with goat milk every two hours. A few days later, the calf developed minor diarrhoea and was treated with diosmectite, with additional herbal extract (chamomile), oral administration of linseeds and fluid therapy. Antibiotic treatment consisting of amoxicillin (Clamoxyl $150 \mathrm{mg} / \mathrm{ml}$ ) was administered to counter secondary infections. On the 16 June, an apparent improvement in its physical condition was noticed: the calf resumed normal appetite (diet consisting of goat milk, hay, crushed oats and tree twigs ad libidum), and was very active.

On the afternoon of 22 June, the calf presented with apathy, anorexia and an ataxic gait. Body temperature was $40.6^{\circ} \mathrm{C}$. Babesia infection was suspected and treatment with imidocarb dipropionate (Carbesia, MSD Intervet; in a single dose recommended for bovines: $0.85 \mathrm{mg} / 1 \mathrm{~kg}$ ) was initiated. The calf received also intravenous fluids, amoxicillin (intravenous Clamoxyl $150 \mathrm{mg} / \mathrm{ml}$ ) and methylprednisolone (Solu-Medrol $250 \mathrm{mg} / 4 \mathrm{ml}$ ).

Temporal improvement was observed during the following night, with a reduction in body temperature $\left(37.9^{\circ} \mathrm{C}\right)$, and an increase in activity and appetite. On the morning of 23 June, the calf received fluid supply and Catosal $10 \%$; however, by the early afternoon of the same day the animal suffered a rapid relapse and babesiosis symptoms were observed: calf was recumbent, refused food, its body temperature was $39.0^{\circ} \mathrm{C}$, and the mucous membranes were pale. Despite continuous intravenous fluid therapy, the calf died a few hours later.

Laboratory diagnostics. DNA was extracted from $100 \mu \mathrm{l}$ of blood and 25mg of spleen samples by use of Qiagen DNeasy Blood and Tissue Kit (Qiagen, Hilden, Germany), respectively, following the manufacturer's instructions.

For the detection of Babesia spp., a single-step PCR was used to amplify the 560 bp $18 \mathrm{~S}$ rRNA gene fragment of Babesia/Theileria $[10,11]$. For genotyping of Babesia-positive samples, an almost a full-length $18 \mathrm{~S}$ rDNA (1700 bp) was amplified with apicomplexan $18 \mathrm{~S}$ rRNA-specific primers Nbab1F 5'-AGCCATGCATGTCTAAGTATAAGCTTTT-3' [12] and TB Rev 5'-AATAATTCACCGGATCACTCG-3' [13] encompassing two of three base positions (positions 631 and 663 of the full gene), described previously as discriminating between $B$. capreoli and $B$. divergens [14]. Positive samples were sequenced by a private company (Genomed S.A., Warsaw, Poland).

For the phylogenetic analysis of Babesia, the Akaike information criterion was used in the jModel Test to identify the most appropriate model of nucleotide substitution. A representative tree for $18 \mathrm{~S}$ rDNA of Babesia spp. was constructed using MEGA v. 7.0, by the Maximum Likelihood method and Kimura 2-parameter model. Additionally, to detect Babesia infection in elk, samples (blood and spleen), a $328 \mathrm{bp}$ fragment of cox 1 gene was amplified, as described previously [9].

The samples were also screened for tick-borne bacteria: amplifying Borrelia burgdorferi s.l. (Borreliella spp.) fla gene sequence, and for A. phagocytophilum and Ca. Neoehrlichia mikurensis (CNM), amplifying 16S rDNA - rss gene fragments, as described previously in detail $[15,16]$.

Finally, to determine the ecotype of detected A. phagocytophilum, groEL gene fragment was amplified according to the protocol of Alberti et al. [17]. Using the MAFFT algorithm [18], the A. phagocytophilum sequences were aligned with identical sequences from the GenBank database (recognized by BLAST NCBI) and reference sequences from Jahfari et al. [19]. A Maximum Likelihood tree was constructed using automatic parameters on the IQ-TREE web server [20].

\section{RESULTS}

DNA of tick-borne pathogens was found only in roe deer samples (Tab. 1). The blood sample from the elk calf tested negative in both PCR protocols for Babesia spp. Two roe deer tested positive for $A$. phagocytophilum $(2 / 7=28.6 \%)$. One of these calves also tested positive for Babesia. Interestingly, splenomegaly was observed during necropsy in these two infected calves (Tab. 1). The calf diagnosed in the present study with co-infection of Babesia and A. phagocytophilum died from unknown causes, and did not receive any treatment for babesiosis or anaplasmosis.

Table 1. Sample characteristics and tick-borne infections

\begin{tabular}{|c|c|c|c|c|c|}
\hline $\begin{array}{l}\text { Sample } \\
\text { identifier }\end{array}$ & $\begin{array}{l}\text { Host species } \\
\text { and gender }\end{array}$ & $\begin{array}{l}\text { Host weight } \\
\text { and age }\end{array}$ & $\begin{array}{c}\text { Babesia } \\
\text { spp. }\end{array}$ & $\begin{array}{l}\text { A. phago- } \\
\text { cytophilum }\end{array}$ & $\begin{array}{l}\text { Necropsy } \\
\text { findings }\end{array}$ \\
\hline R1 & $\begin{array}{l}\text { Roe deer, } \\
\text { female }\end{array}$ & $\begin{array}{c}1.5 \mathrm{~kg}, \\
\text { few days }\end{array}$ & - & - & Head trauma \\
\hline R2 & $\begin{array}{l}\text { Roe deer, } \\
\text { male }\end{array}$ & $\begin{array}{c}2 \text { kg, } \\
\text { few days- } \\
\text { week }\end{array}$ & - & - & $\begin{array}{c}\text { Left hind leg } \\
\text { missing } \\
\text { (trauma) }\end{array}$ \\
\hline R3 & $\begin{array}{l}\text { Red squirrel, } \\
\text { female }\end{array}$ & $\begin{array}{l}0.5 \mathrm{~kg} \\
\text { adult }\end{array}$ & - & - & - \\
\hline R4 & $\begin{array}{l}\text { Roe deer, } \\
\text { female }\end{array}$ & $\begin{array}{l}1.7 \mathrm{~kg} \\
\text { few days }\end{array}$ & - & - & - \\
\hline R5 & $\begin{array}{l}\text { Roe deer, } \\
\text { male }\end{array}$ & $\begin{array}{c}4 \mathrm{~kg}, \\
\text { few weeks }\end{array}$ & - & - & splenomegaly \\
\hline R6 & $\begin{array}{c}\text { European } \\
\text { beaver, } \\
\text { female }\end{array}$ & $\begin{array}{c}1 \text { kg, } \\
\text { juvenile }\end{array}$ & - & - & $\begin{array}{c}\text { Numerous } \\
\text { wounds (dog } \\
\text { bites) }\end{array}$ \\
\hline R7 & $\begin{array}{l}\text { Roe deer, } \\
\text { female }\end{array}$ & $\begin{array}{c}3 \mathrm{~kg}, \\
\text { few weeks }\end{array}$ & - & - & Head trauma \\
\hline R8 & $\begin{array}{l}\text { Roe deer, } \\
\text { female }\end{array}$ & $\begin{array}{c}6 \mathrm{~kg}, \text { few } \\
\text { weeks }\end{array}$ & - & + & Splenomegaly \\
\hline R9 & $\begin{array}{l}\text { Red fox, } \\
\text { female }\end{array}$ & $\begin{array}{c}3 \mathrm{~kg}, \\
\text { several } \\
\text { weeks }\end{array}$ & - & - & $\begin{array}{c}\text { Fluid in heart } \\
\text { and body } \\
\text { cavity }\end{array}$ \\
\hline R10 & $\begin{array}{l}\text { Eurasian elk, } \\
\text { female }\end{array}$ & $\begin{array}{c}20 \mathrm{~kg}, \\
\text { few weeks }\end{array}$ & + & - & - \\
\hline R11 & $\begin{array}{l}\text { Roe deer, } \\
\text { male }\end{array}$ & $\begin{array}{c}2 \mathrm{~kg}, \\
\text { few days }\end{array}$ & + & + & splenomegaly \\
\hline Total & & & $\begin{array}{c}2 / 8 \\
\text { cervids }\end{array}$ & $2 / 8$ cervids & \\
\hline
\end{tabular}




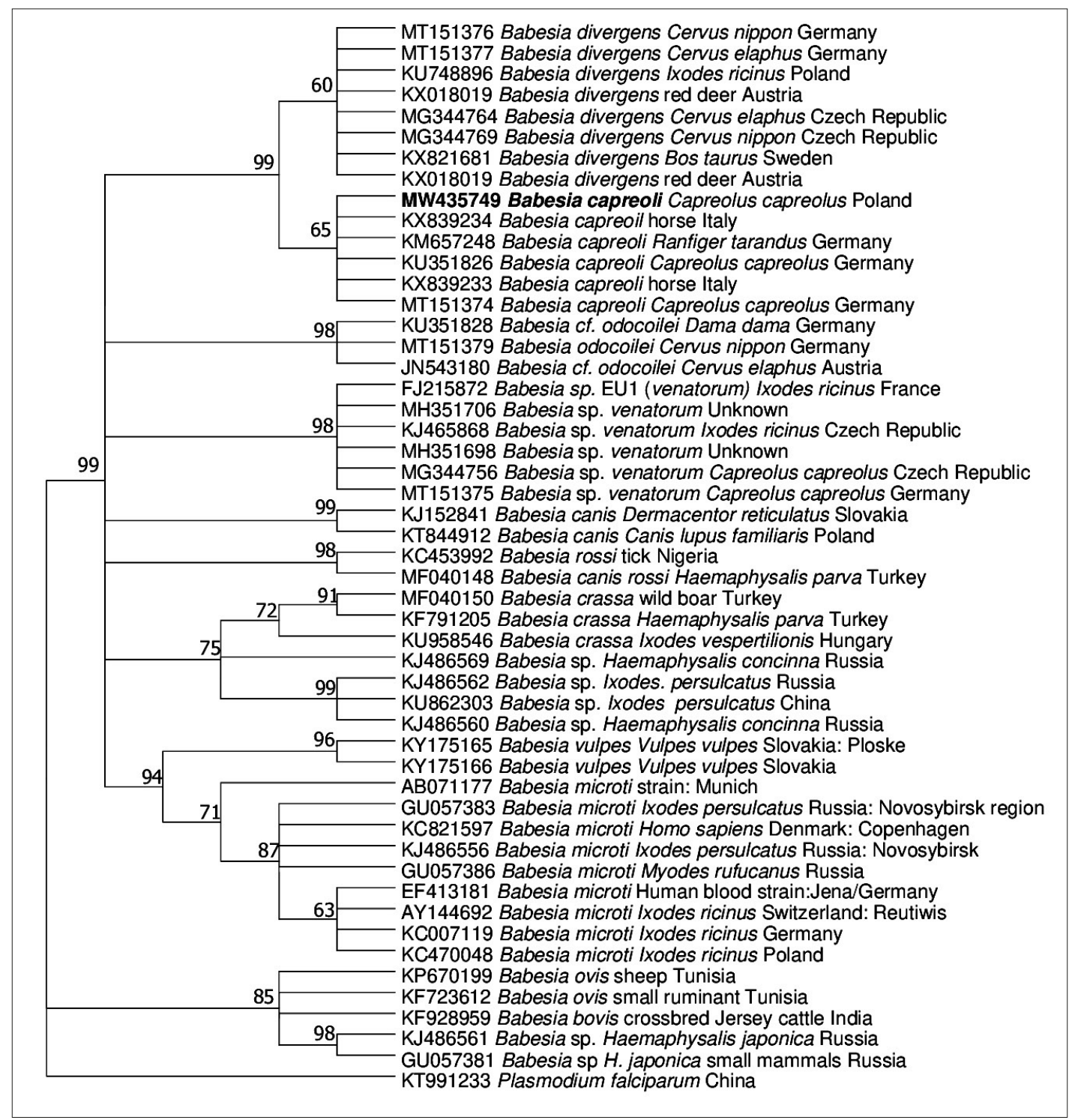

Figure 1. Phylogenetic tree of Babesia spp. based on a fragment of the $18 \mathrm{~S}$ rRNA gene (550bp).

The evolutionary history was inferred by using the Maximum Likelihood method based on the Kimura 2-parameter model. The tree with the highest log likelihood (-2301.03) is shown. The percentage of trees in which the associated taxa clustered together is shown below the branches. Initial tree(s) for the heuristic search were obtained automatically by applying Neighbour-Join and BioNJ algorithms to a matrix of pairwise distances estimated using the Maximum Composite Likelihood (MCL) approach, and then selecting the topology with superior log likelihood value. A discrete Gamma distribution was used to model evolutionary rate differences among sites (five categories $(+G$, parameter $=2.0325))$. The analysis involved 51 nucleotide sequences. All positions containing gaps and missing data were eliminated. There was a total of 336 positions in the final dataset. Evolutionary analyses were conducted in MEGA7.

Babesia species identification. A consensus sequence of $18 \mathrm{~S}$ rDNA (about $900 \mathrm{bp}$ ) displayed $100 \%$ similarity to B. capreoli (FJ944828) and 99.78\% similarity to B. divergens (FJ944826). Analysis of discriminating positions (positions 631 and 663 of the full gene) revealed the presence of B. capreoli SNPs (G, T). Phylogenetic analysis (Fig. 1) showed that the presented Babesia sequence grouped with B. capreoli sequences obtained from various deer species (mostly roe deer) from different European countries. The $18 \mathrm{~S}$ rDNA B. capreoli sequence from the roe deer calf was deposited in the GenBank database under Accession No. MW435749.

Anaplasma phagocytophilum identification. Both rrs 897 bp consensus sequences showed $100 \%$ similarity to two known sequences of $A$. phagocytophilum (HQ629914, AJ242783) and clustered within non-zoonotic lineage 2 of A. phagocytophilum, among sequences originating from
I. ricinus and roe deer in Europe [21]. One A. phagocytophilum rrs sequence was deposited in the GenBank under Accession No. MW879362.

One obtained groEL sequence (R8) (MZ090590) was identical with $A$. phagocytophilum from $I$. ricinus tick from Estonia (HQ629905) and from roe deer from Switzerland (AF383225), whereas the second sequence (R11) (MZ090591) was identical with $A$. phagocytophilum from $I$. ricinus from Slovenia (KM215250), elk from Sweden (KC800984) and roe deer from Austria (AY220467).

The phylogenetic tree of total 526 sequences (Supplementary Fig. 1) showed that both sequences obtained in the current study belonged to ecotype 2 , together with isolates from ruminants, rodents and Ixodes ticks of Central and Eastern Europe [19].

All samples were negative for B. burgdorferi s.l./Borreliella spp. and CNM. 


\section{DISCUSSION}

The present study has demonstrated that tick-borne infections/co-infections can be identified already in cervid calves only few-weeks old, and could have contributed to mortality despite applied treatment.

During necropsy, an apparent enlargement of the spleen was observed in two roe deer calves, one diagnosed with A. phagocytophilum infection alone and one with co-infection of A. phagocytophilum and B. capreoli. Splenomegaly is one of the common pathological symptoms in Babesia- or A. phagocytophilum-infected animals and humans; reported in both experimentally- or naturally-infected animals [9, $22,23]$. Among Babesia species infecting deer, B. capreoli is the most pathogenic and was recently re-described based on comparison with $B$. divergens [14]. Interestingly, this Babesia species seems to be abundant not only in roe deer but also occurs sporadically in other deer species (red deer, sika deer, Père David's deer, fallow deer, reindeer) $[14,24$, $25,26,27]$. This piroplasm species can cause acute and fatal disease in roe deer, Père David's deer and reindeer. The clinical signs and necropsy features reported previously in roe deer were typical of babesiosis, and included icterus, haemoglobinuria, haematuria, splenomegaly, haemosiderosis of liver and spleen, and pulmonary oedema [14].

In the current study it was not possible to confirm Babesia infection in the elk calf presenting with acute babesiosis. However, this failure could have been attributed to the intensive anti-Babesia treatment the calf had received before sampling (see: case description). Veterinary staff at the rescue centre had long-time experience with the diagnosis and treatment of babesiosis as the centre is localized in Babesia canis hyper-endemic region resulting with hundreds of babesiosis cases in dogs $[28,29,30]$. Thus, their diagnosis is included here and we may conclude that in addition to road accidents, habitat fragmentation and grey wolf predation [31, $32,33]$, tick-borne infections may constitute an additional significant limitation on the growth and spread of elk populations in the region. To date, at least three Babesia species ( $B$. venatorum, $B$. capreoli, $B$. odocoilei-like) have been found in Eurasian elk [34, 35].

Anaplasma phagocytophilum detected in two roe deer calves in this study was identified as non-zoonotic ecotype 2 , specific to rodents and ruminants, and also found in Ixodes ticks [19]. It is plausible that co-infection with A. phagocytophilum, known for its immunosuppressive properties and pathogenicity in mammalian hosts [36], could have been a factor triggering fatal systemic breakdown in the identified co-infection with $B$. capreoli in roe deer calf.

Conclusion: Tick-borne pathogens can be found in juvenile cervids and may contribute to mortality among cervid calves.

\section{DECLARATIONS}

Ethics approval and consent to participate: not applicable. Consent for publication: not applicable Availability of data and materials: all data generated or analysed during this study are included in this published article. Competing interests: the authors declare that they have no competing interests. Funding: the study was supported by the National Science Centre (NCN) Sonata Bis grant no. 2014/14/E/ NZ7/00153 (AB). Authors' contributions: AB conceived the study and prepared ms; AB, MK, MA and DDS performed the sampling and laboratory analyses. DDS and MK performed phylogenetic analyses.

\section{Acknowledgements}

The authors express their thanks to Professor Jerzy M. Behnke at the University of Nottingham, UK, for the critical review and linguistic proofreading of this article.

\section{REFERENCES}

1. Rosef O, Paulauskas A, Radzijevskaja J. Prevalence of Borrelia burgdorferi sensu lato and Anaplasma phagocytophilum in questing Ixodes ricinus ticks in relation to the density of wild cervids. Acta Vet Scand. 2009; 27: 47. doi: 10.1186/1751-0147-51-47

2. Medlock JM, Hansford KM, Bormane A, et al. Driving forces for changes in geographical distribution of Ixodes ricinus ticks in Europe. Parasit Vectors. 2013; 6: 1.

3. Borowik T, Cornulier T, Jędrzejewska B. Environmental factors shaping ungulate abundances in Poland. Acta Theriol. 2013; 58: 403-413.

4. Orłowska L, Rembacz W. Population dynamics and structure of roe deer (Capreolus capreolus) inhabiting small-size forests in north-western Poland. Folia Zool. 2016: 6552-6558.

5. Panek M. Sytuacja zwierzyny łownej w Polsce - wyniki monitoringu 2019. Stacja Badawcza PZł Czempiń. 2020: 3-4. (in Polish).

6. Raczynski J, Ratkiewicz M. Funkcjonowanie populacji łosia w Polsce. Ann Warsaw Univ Life Sci - SGGW. 2011; 50: 51-56. (in Polish).

7. Borowik T, Ratkiewicz M, Maślanko W, Duda N, et al. Living on the edge - the predicted impact of renewed hunting on moose in national parks in Poland. Basic Appl Ecol. 2018; 30: 87-95.

8. Hodžić A, Alić A, Fuehrer HP, et al. A molecular survey of vector-borne pathogens in red foxes (Vulpes vulpes) from Bosnia and Herzegovina. Parasit Vectors. 2015; 8: 88.

9. Mierzejewska EJ, Dwużnik D, Koczwarska J, et al. The red fox (Vulpes vulpes), a possible reservoir of Babesia vulpes, B. canis and Hepatozoon canis and its association with the tick Dermacentor reticulatus occurrence. Ticks Tick Borne Dis. 2021; 12: 101551.

10. Bonnet S, Jouglin M, L'Hostis M, et al. Babesia sp. EU1 from roe deer and transmission within Ixodes ricinus. Emerg Infect Dis. 2007; 13: 1208-1210. doi: 10.3201/eid1308.061560

11. Bonnet S, Jouglin M, Malandrin L, et al. Transstadial and transovarial persistence of Babesia divergens DNA in Ixodes ricinus ticks fed on infected blood in a new skin-feeding technique. Parasitol. 2007; 134: 197-207. doi: 10.1017/S0031182006001545

12. Oosthuizen MC, Zweygarth E, Collins NE, et al. Identification of a novel Babesia sp. from a sable antelope (Hippotragus niger Harris, 1838). J Clin Microbiol. 2008; 46: 2247-2251.

13. Matjila PT, Leisewitz AL, Oosthuizen MC, et al. Detection of a Theileria species in dogs in South Africa. Vet Parasitol. 2008; 157: 34-40.

14. Malandrin L, Jouglin M, Sun Y, et al. Redescription of Babesia capreoli (Enigk and Friedhoff, 1962) from roe deer (Capreolus capreolus): isolation, cultivation, host specificity, molecular characterisation and differentiation from Babesia divergens. Int J Parasitol. 2010; 40: 277284.

15. Kowalec M, Szewczyk T, Welc-Falęciak R, et al. Ticks and the city - are there any differences between city parks and natural forests in terms of tick abundance and prevalence of spirochaetes? Parasit Vectors. 2017; 10: 573.

16. Kowalec M, Szewczyk T, Welc-Faleciak R, et al. Rickettsiales occurrence and co-occurrence in Ixodes ricinus ticks in natural and urban areas. Microb Ecol. 2019; 77: 890-904. doi: 10.1007/s00248-018-1269-y

17. Alberti A, Zobba R, Chessa B, A et al. Equine and canine Anaplasma phagocytophilum strains isolated on the island of Sardinia (Italy) are phylogenetically related to pathogenic strains from the United States. Appl Environ Microbiol. 2005; 71: 6418-6422. doi: 10.1128/ AEM.71.10.6418-6422.2005

18. Katoh K, Misawa K, Kuma K, et al. MAFFT: a novel method for rapid multiple sequence alignment based on fast Fourier transform. Nucleic Acids Res. 2002; 30: 3059-3066.

19. Jahfari S, Coipan EC, Fonville M, et al. Circulation of four Anaplasma phagocytophilum ecotypes in Europe. Parasit Vectors. 2014; 7: 365.

20. Trifinopoulos J, Nguyen LT, von Haeseler A, et al. W-IQ-TREE: a fast online phylogenetic tool for maximum likelihood analysis. Nucleic Acids Res. 2016; 8: W232-235. 
21. Katargina O, Geller J, Alekseev A, et al. Identification of Anaplasma phagocytophilum in tick populations in Estonia, the European part of Russia and Belarus. Clin Microbiol Infect. 2012; 18: 40-46.

22. Welc-Faleciak R, Bajer A, Bednarska M, et al. Long term monitoring of Babesia microti infection in BALB-c mice using nested PCR. Ann Agric Environ Med. 2007; 14: 287-290.

23. Krause PJ. Human babesiosis. Int J Parasitol. 2019; 49: 165-174.

24. Welc-Falęciak R, Werszko J, Cydzik K, et al. Co-infection and genetic diversity of tick-borne pathogens in roe deer from Poland. Vector Borne Zoonotic Dis. 2013; 13: 277-288.

25. Michel AO, Mathis A, Ryser-Degiorgis MP. Babesia spp. in European wild ruminant species: parasite diversity and risk factors for infection. Vet Res. 2014; 45: 1-11.

26. Silaghi C, Fröhlich J, Reindl H, et al. Anaplasma phagocytophilum and Babesia species of sympatric roe deer (Capreolus capreolus), fallow deer (Dama dama), sika deer (Cervus nippon) and red deer (Cervus elaphus) in Germany. Pathogens. 2020; 9: 968.

27. Azagi T, Jaarsma RI, Docters van Leeuwen A, et al. Circulation of Babesia Species and their exposure to humans through Ixodes ricinus. Pathogens. 2021; 10: 386. doi: org/10.3390/pathogens10040386

28. Dwużnik-Szarek D, Mierzejewska EJ, Rodo A, et al. Monitoring of expansion of Dermacentor reticulatus and occurrence ofcanine babesiosis in Poland in 2016-2018. Parasit Vectors. 2021; 14: 267. doi: org/10.1186/s13071-021-04758-7

29. Bajer A, Mierzejewska EJ, Rodo A, et al. The risk of vector-borne infections in sled dogs associated with existing and new endemic areas in Poland: Part 1: A population study on sled dogs during the racing season. Vet Parasitol. 2014; 202: 276-286. doi: 10.1016/j. vetpar.2013.12.033

30. Bajer A, Mierzejewska EJ, Rodo A, et al. The risk of vector-borneinfections in sled dogs associated with existing and new endemic areas in Poland. Part 2: Occurrence and control of babesiosis in a sled dog kennel during a 13-year-long period. Vet Parasitol. 2014; 202: 234-240.

31. Jedrzejewski W, Schmidt K, Theuerkauf J, et al. Kill rates and predation by wolves on ungulate populations in Bialowieza Primeval Forest (Poland). Ecology. 2002; 83: 1341-1356.

32. Dziki-Michalska K, Tajchman K, Budzyńska M. Increase in the moose (Alces alces L. 1758) population size in Poland: causes and consequences. Ann Warsaw Univ Life Sci - SGGW. 2019; 58: 201-214.

33. Borowik T, Ratkiewicz M, Maślanko W, et al. 2020. The level of habitat patchiness influences movement strategy of moose in Eastern Poland. PLoS ONE 15: e0230521.

34. Malmsten J, Dalin AM, Moutailler S, et al. Vector-borne zoonotic pathogens in Eurasian moose (Alces alces alces). Vector Borne Zoonotic Dis. 2019; 19: 207-211.

35. Puraite I, Rosef O, Radzijevskaja J, et al. The first detection of species of Babesia Starcovici, 1893 in moose, Alces alces (Linnaeus), in Norway. Folia Parasitol (Praha). 2016; 63: 1-5.

36. Matei IA, Estrada-Peña A, Cutler SJ, et al. A review on the ecoepidemiology and clinical management of human granulocytic anaplasmosis and its agent in Europe. Parasit Vectors. 2019; 12: 599. doi.org/10.1186/s13071-019-3852-6 